\title{
SPODOPTERA FRUGIPERDA (LEPIDOPTERA: NOCTUIDAE), AN INVASIVE PEST IN AGRICULTURAL CROPS AND ITS MANAGEMENT
}

\author{
Ahmad Hassan Tahir, Muhammad Tariq, Aqsa Mazhar, Muhammad Shehzad \\ Department of Entomology, Pir Mehr Ali Shah Arid Agriculture University Rawalpindi, Pakistan.
}

\section{ART I C L E I N F O}

\section{Article history}

Received: $17^{\text {th }}$ September, 2020

Revised: $29^{\text {th }}$ November, 2020

Accepted: 27th December, 2020

\section{Keywords}

Fall armyworm

Invasive agricultural pest

Identification

Integrated pest

management

\begin{abstract}
A B S T R A C T
Spodoptera frugiperda (Lepidoptera: Noctuidae) commonly known as fall armyworm (FAW), is a pest that invaded the sub-tropical and tropical regions of America. In 2016, it was reported for the first time in central Africa and within a year it was reported from many countries of Africa. It then spread in Asia and in 2018 it was reported in India, and now its infestation was seen in Pakistan. Its strong flight, climatic adaptableness and large host range makes it a good colonizing agent as compared to other species of Spodoptera. In potential managing strategies we must know about its primary information such as its biology, host range, habitat and favorable conditions. Identification and life cycle is the most important process in the management of this pest. IPM strategies include physical and cultural control, botanical control, biological control and chemical control. These strategies will help in management of FAW. All these aspects have been reviewed in this article.
\end{abstract}

Corresponding Author: Ahmad Hassan Tahir

Email: 15arid4878aaur@gmail.com

(C) 2020 EScience Press. All rights reserved.

\section{INTRODUCTION}

Fall armyworms (FAW), Spodoptera frugiperda (J.E. Smith) (Lepidoptera: Noctuidae) are native to tropical and sub-tropical regions of America. In 2016, it was reported for the first time in central Africa and within a year it was reported from many countries of Africa. It then spread in Asia and in 2018 it was reported in India, and now its infestation was seen in Pakistan. In winter season, FAW normally overwinters successfully and in summer it can disperse in many states and countries annually, due to its strong and long distance flying nature. A single generation of adult moth can travel about 300 miles with the help of wind current, before they reach ovipositional stage (Prasanna et al., 2018). It is the most harmful pest which feeds on a large number of agricultural crops and causes severe damage. Fall army worm mainly feeds on maize crop and affects its yield about $20 \%$ to $50 \%$. Corn is considered as one of the major agricultural crop around the world and is used as human food, industry products and animal fodder (Visser, 2017).

The pest is polyphagous in nature and its host range includes cotton, vegetables, cereals, grains and fodder crops. It cause defoliate to host plant. FAW is an insect showing polyphagous nature, with more than 80 host species, causing severe damage to cereals and vegetable crops (Goergen et al., 2016). Its larvae consume foliage and cause damage to plants. Young ones feed on epidermal tissue of leaves and holes are formed in leaves. Caterpillar also feeds on young plants and causes dead heart, which is a common symptom of FAW. Invasive pests are extrinsic or non-endemic pests that 
are present other than their naturally preferred location. Such invasion occurs due to natural selection process or it may be due to human interventions. FAW can establish itself in new environment and increase their population potentially (Nidhi et al., 2018).

The preferred management measure for FAW is integrated pest management (IPM) which is based on a combination of control methods which is more effective, causes minimum risk to the environment and human life. Successful implementation of IPM is possible with effective monitoring activity. Light and pheromones traps are used in the monitoring of FAW. Commonly aggregation pheromone and sex pheromones are used (Prasanna et al., 2018). Light traps are also used to capture the adult moths. Biocontrol agents can be used for the management of FAW because of their nonnegative effects on human life and environment, but biological control is a slow process and less effective due to rapid increase population of FAW. So low risk biopesticides are used in the management of FAW. These biopesticides are based on biochemical and microbial pest management products. Option for using insecticides is not preferred due to their high risks but their effective results attract the consumers and used on many crops in the field.

\section{IDENTIFICATION}

Female of FAW lays 100 to 200 eggs in total life span. Eggs are laid naturally in clustered form. Eggs are droso ventrally flattened. Female lays eggs on the upper and lower side of leaves. Incubation period is completed with 23 days. Their color is greenish gray in early days and later on turns into brown. Before hatching, it changes into black color. Female cover eggmass with layers of scales known as downy materials. It gives moldy appearance. There are six instars in FAW larvae. $1^{\text {st }}$ instar larvae are greenish in color and black head capsule, and second instars turned greenish brown. Brownish three dorsal and lateral white lines appear at third instar stage. Larvae darken in color as they feed and appear greenish (Luginbill, 2017 ). Notable inverted " $\mathrm{Y}$ " on the head capsule is observed in the larvae (Oliver and Chapin, 1981). The antennae of FAW are filiform (threadlike) (Figure 1a-c).
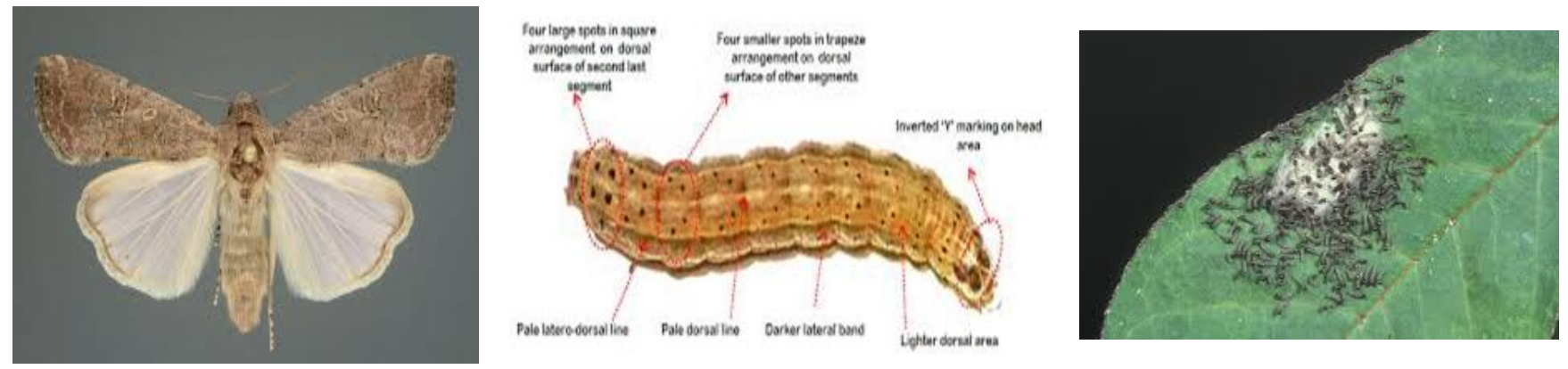

Figure 1: a) Adult of FAW, b) Larva of FAW, c) $1^{\text {st instar larvae }}$

\section{Damage symptoms}

The larvae feed on several crops but maize is the most preferred one. It feeds on all stages of maize, but mostly prefers the young stage with whorl. It includes in voracious feeder thus consume a lot of foliage, eats young growing plants and leads to crop failure. Young ones eat the leaf tissues and make thin patches on leaves, whereas later instars make large holes on leaves and maize stem. This pest causes typical dead heart on crops and thereby effected plants is completely fail (Rwomushana et al., 2018).

\section{Host crops and ETL of the pest}

FAW is serious polyphagous crop pest having voracious nature and wide host range, approximately more than 100 plant species belong to 27 families. Preferred plants are mostly from Graminae family including other many economically and commercially important plants such as cotton, maize, sorghum, millet, sugarcane, wheat, rice, etc. Its infestation is also reported on many other field crops such as groundnut, cowpea, potato, soybean, etc. Up to $35 \%$ damage on maize crop by FAW has been reported. The economic threshold level or ETL (when control measures have to be taken to prevent from pest population increase and keep them from economic injury level (EIL) of the pest is the benchmark level. There are 3 ETL levels of FAW which are following:

A) 1-2 Larvae per each whorl

B) $5 \%$ to $6 \%$ Seedling are cut

C) 1 st 30 days young plants shows $15 \%$ whorl infestation 


\section{Scouting and monitoring}

Scouting is done by regularly monitoring the crop for infestation of FAW. It is always easy to manage the pest population if it is detected in early stages. Scouting for pest is done by locating five spots in the field, excluding border areas. The selected spots or locations must be in zigzag fashion. Select 10 plants from each spot and closely monitored each location for infestation of FAW. Immediate action is required for the management of FAW if 10 plants are infested out of 50 plants, otherwise crop will completely destroy. Light traps and pheromones traps are used effectively in the monitoring of fall armyworm. Mostly used pheromones are aggregation pheromones and sex pheromones (Prasanna et al., 2018). Black light traps are also used for capturing adult moths. Pest scouting helps us to be better preparation for any pest attack and to be able to take a timely action. Management of any pest began with prevention. Approximately 5- 10 traps are used to trap the male moths in one hectare. Numbers of FAW in each trap are recorded, counted, and used to decide for further action plans for the managing of insect.

\section{Integrated pest management}

Problem with the invasive pest and why it is difficult to manage them is that they are from other locations and invades suddenly. This gives us with limited information regarding the pest and its management. Major challenge is the identification of pest. Wrong identification of pest can lead to improper managing practices. Sometime potential natural enemies are restricted to its native land and do not move along with invading pest. Such pests are proliferators and vigorous feeder. If they establish in new location, it is very difficult to manage them. The chemicals used to kill them are not to be very effective because pest shows already resistant to many of them so it further takes more time to find out the right option to manage them. Due to the above mentioned factors it is always necessary to adopt an integrated and holistic approach for the management of the FAW and not only depending on the chemical control. All the given tools of the integrated pest management should be integrated to combat this invasive pest (Alastair, 2003; Orr, 2003).

\section{A) Cultural and physical control}

It is the main component in the management strategy of FAW. The resilient or resistant varieties of crop should be used for lesser incidence of pest occurrence. A well crop rotation program should be revised so that pests do not come towards the desired host. By doing this the proliferation and spread of the pest may be low. Also, staggered and late planting of crops must be avoided because it leads to great pest infestation. Sowing date plays a very important role in the management. The pest can be controlled by hand picking of the eggmass during the regular monitoring of field. It helps to manage pest in small scale and it has been proved somewhat successful. The well management of crop residues also used in order to break the cycle of FAW, as pest use crop residue as an inoculum bank and it leads to the spread of pest in next season as well.

\section{B) Biological control}

Entomopathogenic fungus like Nomuraea rileyi, Beauveria bassiana and Metarhizium spp. are used effectively to control the pest population not just for current season but it also provides immunity to crops for the second season due to building up of inoculum in soil. Natural enemies are also used to manage the pest like Trichogramma sp., Telenomous sp. The most effective entomophagus insect is social wasp which is used to manage lepidopterous. The use of genetically modified crops that contain Bt genes, produce protein that is toxic to larvae of FAW. Mass trapping of male moths by using pheromones, preventing them from mating (Day et al., 2017 ) are some of the important biological controls. The important predatory insects are ladybird beetles, earwigs, ants, and some bugs (Goergen et al., 2016).

\section{C) Botanical control}

Azadirachtin is a natural biopesticide that is extracted from neem (Azadirachta indica) trees. It has shown a broad spectrum of antimolting and antifeedant effects in a large number of agricultural pests. Two to three sprays of Azadirachtin are done at the interval of 7-10 days, alone or in integration with the chemical for controlling the pest. It also inhibits the growth and multiplication of pests and is also harmless to humans and animals (Reed and Majumdar, 1998).

\section{D) Chemical control}

A lot of chemicals are available for combating the pest and care must be taken to choose right solution to manage the FAW. The chemical control starts from the seed treatment.

\section{Seed treatment}

The seeds of corn should be treated with Cyantraniliprole 19.8\% + Thiamethoxam 19.8\% FS @ 6 $\mathrm{ml} / \mathrm{kg}$ of seed and this will be effective for 15-20 days.

First window (Seedling to early whorls stage) To manage FAW larvae which are freshly hatched and 
cause 5\% of damage, use 5\% NSKE/ Azadirachtin 1500 ppm with $5 \mathrm{ml} / \mathrm{L}$ of water and spray the affected crop. Second window (From mid whorls to late whorls stage) Late whorls are mostly formed by $3^{\text {rd }}$ instar larvae. For the management of $2^{\text {nd }}$ and $3^{\text {rd }}$ instars (larvae having more than $10 \%$ foliar damage) the following chemicals can be used up to early tasseling stage: Chlorantraniliprole $18.5 \%$ SC, Spinetoram $11.7 \%$ SC or Lambda cyhalothrin 9.5\% ZC+ Thiamethoxam 12.6\% (Sisay et al., 2019).

\section{Poison baiting}

Poison bait is also recommended for late instars larvae of second window. By using the mixture of 2 kg jaggery $+10 \mathrm{~kg}$ rice bran with 2-3 liter of water. Hundred gram of Thiodicarb may also be added just before the application in the crop. The bait should be applied into whorl of the plants. Biopesticides are also recommended for $5^{\text {th }}$ instar larvae.

\section{Insecticide resistance management}

Insects show resistance towards insecticides because of evolutionary mechanism and insect adaptability to metabolize the chemicals and thus remain immune to pesticides effect. In any population dynamics, there are some better adapted individuals, or they can easily metabolize certain chemicals, whereas other cannot. The pests that can resist chemicals or pesticides are known as resistant. When insect populations are repeatedly exposed towards specific insecticide or a specific group/class of pesticides, in this way the resistant individual survive, and susceptible population is killed. Over a period of time, these resistant pests survive and produce new generation, thereby making the population resistant towards many chemical. Thus, the pesticide rotation programmed should be followed to reduce resistant in insect. It will also helpful in managing the problem of resistance development in pests (Berlinger, 1996; Carvalho, 1970).

The management of FAW should be done by following all the tools of integrated pest management. Only the registered and approved insecticides for the pest management should be used that is in rotation and at recommended dose. One should refuse from using same chemical again and again, even if control achieved is good, as over a period this would lead to resistance development.

\section{Conclusion}

The problem of FAW, in agricultural crops has become a serious matter of its potential damage to various crops.
Thus, the Private and Government sector should work in close coordination to combat the pest and protect the crop. The above review is an effort to better understand the pest, its history, background and invasion rotes. Any kind of management measure can be initiated after having a better understanding of the biology of pest, along with its identification and damage potential is well known. The well improved comprehension of a pest along with its integrated pest management measures enlisted in given review. It will help not only in the management of pest, but also help in pest resistance management.

\section{AUTHOR CONTRIBUTION}

All the authors contributed equally to collect and compile the literature and in its write-up. All the authors took part in its proofreading and editing.

\section{CONFLICT OF INTEREST}

The authors declare no conflict of interest.

\section{REFERENCES}

Alastair, O., 2003. Integrated Pest Management for Resource Poor African Farmers: Is the Emperor Naked? World Development 31, 831-845.

Berlinger, R.G., 1996. Pest Resistance to Pesticides, Department of Entomology. Clemson University, South Carolina, USA.

Carvalho, R.P.L., 1970. Danos, flutuacË aÄ o de populacË aÄ o, controle e comportamento de Spodoptera frugiperda (JE Smith, 1794) susceptibilidade de diferentes genoÂ tipos de milho em condicË oÄ es de campo.(Piracicaba: Imprensa ESALQ) Ph. D, Piracicaba: Imprensa ESALQ) PhD Thesis, p. 170.

Day, R., Abrahams, P., Bateman, M., Beale, T., Clottey, V., Cock, M., Colmenarez, Y., Corniani, N., Day, D., Early, R., Godwin, J.e.a., 2017 Fall armyworm: Impacts and implications for Africa. Outlooks on Pest Management 28, 196-201.

Goergen, G., Kumar, P.L., Sankung, S.B., Togola, A., Tamò, M., 2016. First report of outbreaks of the fall armyworm Spodoptera frugiperda (JE Smith)(Lepidoptera, Noctuidae), a new alien invasive pest in West and Central Africa. PloS one 11, e0165632.

Luginbill, P., 2017 The fall armyworm. USDATech. Bull. No, 1928, 34.

Nidhi, K., Joshi, M., Pandey, R., Anand, K., 2018. Fall army worm: An invasive pest in India and its management.1st editon, CIMMYT: Edo Mex, Mexico. 
Oliver, A.D., Chapin, J.B., 1981. Biology and illustrated key for the identification of twenty species of economically important noctuid pests. Louisiana Agricultural Experiment Station Bulletin No, 1981, 733.

Orr, A., 2003. Integrated pest management for resourcepoor African farmers: Is the emperor naked? World Development 31, 831-845.

Prasanna, B.M., Huesing, J.E., Eddy, R., Peschke, V.M., 2018. Fall armyworm in Africa: a guide for integrated pest management, 1st ed. CIMMYT, Mexico.

Reed, E., Majumdar, S.K., 1998. Differential cytotoxic effects of azadirachtin on Spodoptera frugiperda and mouse cultured cells. Entomologia Experimentalis et Applicata 89, 215-221.
Rwomushana, I., Bateman, M., Beale, T., Beseh, P., Cameron, K., Chiluba, M., Clottey, V., Davis, T., Day, R., Early, R., Godwin, J., Gonzalez-Moreno, P., Kansiime, M., Kenis, M., Makale, F., Mugambi, I., Murphy, S., Nunda. W., Phiri, N., Pratt, C., Tambo, J., 2018. Fall armyworm: Impacts and implications for Africa, Evidence Note Update, October 2018.

Sisay, B., Tefera, T., Wakgari, M., Ayalew, G., Mendesil, E., 2019. The efficacy of selected synthetic insecticides and botanicals against fall armyworm, Spodoptera frugiperda, in maize. Insects 10, 45.

Visser, D., 2017. Fall armyworm: an identification guide in relation to other common caterpillars, a South African perspective. Fall armyworm: an identification guide in relation to other common caterpillars, a South African perspective. 